\title{
nature
}

17 January 2002 Volume 415 Issue no 6869

\section{Divisions in Euroland}

Twelve European nations this month adopted a common currency. But the goal of creating a unified scientific career structure remains distant. The consequent brain drain will undermine Europe's ability to compete with the United States.

T he euro represents a political leap of faith that Europe's leaders hope will boost the continent's economic power. Even if it succeeds in that regard, however, the single currency may do little to stop the brain drain of young scientists from the continent. The three largest nations within 'Euroland' - Germany, France and Italy - each boast a rich scientific heritage. But many of their young scientific high-flyers cast their eyes across the Atlantic, or at least across the English Channel, when envisaging their future careers.

The dominance of the English language is a powerful factor, but it is not the sole reason for the net migration of scientific talent to North America and Britain. Also important are the highly individual academic career ladders that persist in different continental European countries. Employment rules and social security arrangements are also handled differently between countries. The fact that Euroland is such an academic patchwork tends to deter foreigners, and makes it difficult for natives who have gone abroad to return.

Some progress is being made. The European Commission has supported various programmes to promote the movement of young researchers between the European Union's member states. And in 1999, in Bologna, Italy, education ministers from 29 European countries agreed to harmonize aspects of their higher-education systems. These countries have pledged to introduce by $2010 \mathrm{com}$ parable systems of Bachelors and Masters degrees, and a system of academic credits that will allow students to move between countries.

But despite these welcome initiatives, national isolation remains the rule, and no identifiably 'European' scientific career is in sight. It is no wonder that the continent's young scientists are crying out for more consideration to be paid to their plight (see Correspondence, page 259).
In countries such as Italy and Spain, for instance, the academic powers-that-be seem unwilling to reform recruitment systems that favour those who stay at home over — often stronger candidates who have sought experience in foreign labs. Even programmes established with the goal of bringing back talented scientists working abroad have been blighted in this way (see Nature 413, 556; 2001).

Elsewhere, attempts to address national idiosyncrasies have left some problems unsolved. Germany, for instance, the dominant producer of PhDs in Europe, has embarked on an academic reform aimed at creating better opportunities for young scientists (see News Feature, pages 257-258). But there are concerns that the reforms have not been adequately resourced, and also that they will leave stranded those researchers who have been employed on fixed-term contracts for more than 12 years. They must now find a permanent post, or leave academia.

The French government, meanwhile, recently opened up more tenured posts in response to fears about creating a 'lost generation' of researchers, who would not be available to replace the ageing babyboomer generation. But it has not tackled the underlying problem of a system that gives postdocs no official social security status or contract rights, and so forces many French nationals wanting postdoctoral experience to go abroad (see Nature 414, 145; 2001).

If Euroland's best young minds are to move between its nations with the same enthusiasm that currently lures them to North America and Britain, university administrators, immigration offices and society at large must learn that foreign researchers are not troublesome inconveniences, but highly motivated workers who offer their skills to the benefit of their hosts.

\section{Welcome back to the fusion fold?}

The United States should rejoin the ITER project, whose management must communicate better with politicians and public.

G overnments and scientists worldwide will welcome indications that the United States is once again considering participation in ITER, the international project to build an experimental magnetic-confinement fusion reactor (see page 247).

If the United States does rejoin the project, it will send important political signals to the nation's allies, who are concerned about the unilateralist leanings of George W. Bush's administration. ITER is also the largest example of a research project pursued as a genuine collaboration between the world's major scientific powers. In most 'big science' initiatives, such as the US-led International Space Station, other partners have assumed a secondary role. But future projects in disciplines such as high-energy physics will require cooperation on equal terms, and ITER provides the only extant model.

ITER is also important because any real exploration of long-term, sustainable energy must include a thorough technical evaluation of nuclear fusion. Despite theoretical doubts about the ability of a doughnut-shaped magnetic chamber, or tokamak, to contain plasma, such a device remains the best prospect for tapping fusion power.
Before hopping back into bed together, however, the United States and its former partners need to take a careful look at what led to their 1999 estrangement.

Encouraged by the doubters in the US fusion-research community, Congress had lost patience with ITER. The project's management must share the blame, having failed to adapt its design proposal to fiscal realities - not just those in the United States, but those in Europe, Japan and Russia, too - until forced to do so. ITER also failed to sell itself to the public, as any big-ticket project must do in a democratic society.

Bush would do well to buy back into ITER, and to help to rebuild it as a model of scientific collaboration. The mercurial power of Congress to abruptly end funding will remain a threat — reforming the US budget process to provide some security of funding for the nation's international commitments may be just as challenging as containing plasma at a temperature of one million kelvin. In the meantime, ITER's management must do a better public-relations job, and ensure that it does not become distanced from its political paymasters. 